\title{
A Contrastive Survey of Genres of Sanskrit and Tocharian Buddhist Texts
}

Abstract: Most Buddhist documents discovered from the 1st millennium Silk Road cultures are random manuscript fragments from what must once have been huge monastic libraries and archives. This is especially true for the Sanskrit and Tocharian texts in this corpus. The methodological advances in digital humanities now make it possible to investigate the whole available data (that is even very small pieces) by quantitative analysis. The present paper examines the literary genres of Sanskrit and Tocharian fragments found side by side in the remains of Buddhist sites. While the distribution of genres is astonishingly even in most cases, there is a predominance of canonical literature in Sanskrit on the once hand and a predominance of narrative literature in Tocharian on the other. The latter fact supports the assumption that the Tocharian culture freely adopted the Buddho-Indian model beyond mere translation work and established a distinctive narrative/dramatic genre that incorporates preBuddhist elements.

Key words: Tocharian, Sanskrit Buddhist texts, Buddhist genres

The Buddhist manuscripts of the Silk Road cultures, mostly discovered by various expeditions at the end of the 19th and beginning of the 20th cc., are of inestimable value for various areas of study, notably philology and the spread of Buddhism. Unfortunately, in the majority of cases, only manuscript fragments from single leaves from what must once have been voluminous books stored in Buddhist libraries are preserved. However, surveying the preserved material can still reveal much about the use and spread of literacy in the Northern Tarim region during the first millennium CE. The following survey will compare the content of literary Sanskrit and Tocharian (B) fragments that have been discovered side by side in the remains of ancient Buddhist monasteries.

(C) Melanie Malzahn (Univ. of Vienna/BBAW) 
Despite the fragmentary status of both corpora, some facts are certain: both Sanskrit and Tocharian fragments can usually be dated according to their script type; ${ }^{1}$ many fragments can be localized thanks to the recording of find spots by the excavators; due to the effort of one hundred years of meticulous philological work, the contents of many, even small fragments, can be identified.

The following survey of Sanskrit texts is based on the eleven volumes of Sanskrithandschriften aus den Turfanfunden, where 13.530 fragments from the German Turfan Collection are catalogued and described by various editors. ${ }^{2}$ This survey of the Tocharian texts is based on the database of my own project A Comprehensive Edition of Tocharian Manuscripts. ${ }^{3}$ From the corpus of 13.530 Sanskrit fragments, 7.564 were identified by the editors of SHT with respect to text genre, nearly all were assigned to a certain script type, and for 6.430 of them the find spot has been recorded. For Tocharian, there are currently $8.612 \mathrm{~TB}$ and $1.832 \mathrm{TA}$ fragments stored in the CEToM database; for 4.234 of them find spots have been recorded, and all of them can be dated according to script type; 1.292 TB fragments have so far been identified with respect to text genre. In the following, these $1.292 \mathrm{~TB}$ fragments will be compared with the 7.564 identified Sanskrit ones. The TA corpus will not be treated because it is statistically less reliable due the smaller size of the (identified) corpus in general; further, TA texts hail from far fewer find spots and are more homogenous with respect to language stage and script type. On the other hand, the distribution of TB and Sanskrit texts is arguably comparable.

The various find spots can be subsumed under three main regions which in the case of Tocharian B also show specific dialectal traits: the western region around the capital Kuča and its important monastic area Qizil Min-Öy, ${ }^{4}$ the central region around Šorčuq, ${ }^{5}$ and the Turfan

\footnotetext{
${ }^{1}$ See the groundbreaking work by SANDER 1968; for Tocharian, see MALZAHN 2007, TAMAI 2011 and SANDER 2013.

${ }^{2}$ WALDSCHMIDT 1965; WALDSCHMIDT 1968; WALDSCHMIDT 1971; SANDER/WALDSCHMIDT 1980; SANDER/WALDSChMidT 1985; Wille 1989; WiLle 1995; Wille 2000; Wille 2004; Wille 2008; Wille 2012. I would like to thank my student Dimitri Robl for his help in collecting the material.

${ }^{3}$ CEToM at http://www.univie.ac.at/tocharian (retrieved 2017-09-13)

${ }^{4}$ Dō-shamba-bāzār, Duldur-Akhur, Hiçar, Jigdalik, Khitai-bāzār, Kuča, Kuča Min-Öy, Qizil, Qizil Sayram, Qizil Min-Öy, Qizil Qargha, Qumtura, Šaldiray, Simsim, Subeši, Tajik and Tonguzbaš.

${ }^{5}$ In addition, there are the find spots Khōra (Khorabagh Min-Öyi), Qarašähär and Qigexing (Yanqi).
} 
region. ${ }^{6}$ TB texts have also occasionally been found at Dunhuang, Endere, Loulan, Maralbeši, Miran and Tumšuq but in these cases it is likely that texts were brought there from one of the three main dialectal areas.

The following literary genres are attested on paper (or occasionally wooden) fragments ${ }^{7}$ in both Sanskrit and Tocharian: ${ }^{8}$

1. Canon: Doctrine, Vinaya, Abhidharma (including Yoga).

2. Para-canonical literature:

a. Poetry: Buddhastotras, Kāvyas.

b. Narratives/drama: Jātakas/Avadānas, Buddha legend.

3. Scientific and technical literature:

a. Medicine/magic, divination, and calendar.

b. Annals (only attested in TB).

c. Grammar: Grammatical treaties, word lists, syllabaries, writing exercises.

4. Varia: Confessions, donations, blessings.

The analysis of script types applied in SHT is based on Lore Sander's work. ${ }^{9}$ The earliest texts show Kuṣanna and Gupta ductus and can be dated from the $2 \mathrm{nd} / 3 \mathrm{rd}$ up to the 5 th cc. (classified as Types I-III by Sander); we do not have vernacular Tocharian manuscripts from this period, and it is likely that the Tocharians only started writing their own language by establishment of a vernacular version of the Brāhmī script parallel to the establishment of the so-called Turkestan Brāhmī script (Type IV Early Turkestan Brāhmī). ${ }^{10}$ Accordingly, Sanskrit texts written in script Types IIII are to be dated before the production of Tocharian vernacular manuscripts, while Sanskrit manuscripts in script Type IV are roughly contemporary with TB manuscripts in archaic ductus, and Sanskrit script Types V, VI and late-style manuscripts are roughly contemporary with TB classical texts. In the statistical analysis below, these groups are therefore singled out.

\footnotetext{
${ }^{6}$ Bezeklik, Khočo (Dakianus), Murtuq, Qarakhoja, Singim, Toyuq, Turfan foothills and Yar-khoto.

${ }^{7}$ Not included is the occasional graffito or painting caption.

${ }^{8}$ Cf. Pinault 2016, 174.

${ }^{9}$ SANDER 1968.

${ }^{10}$ SANDER 1968, 186; MALZAHN 2007, 277.
} 
6

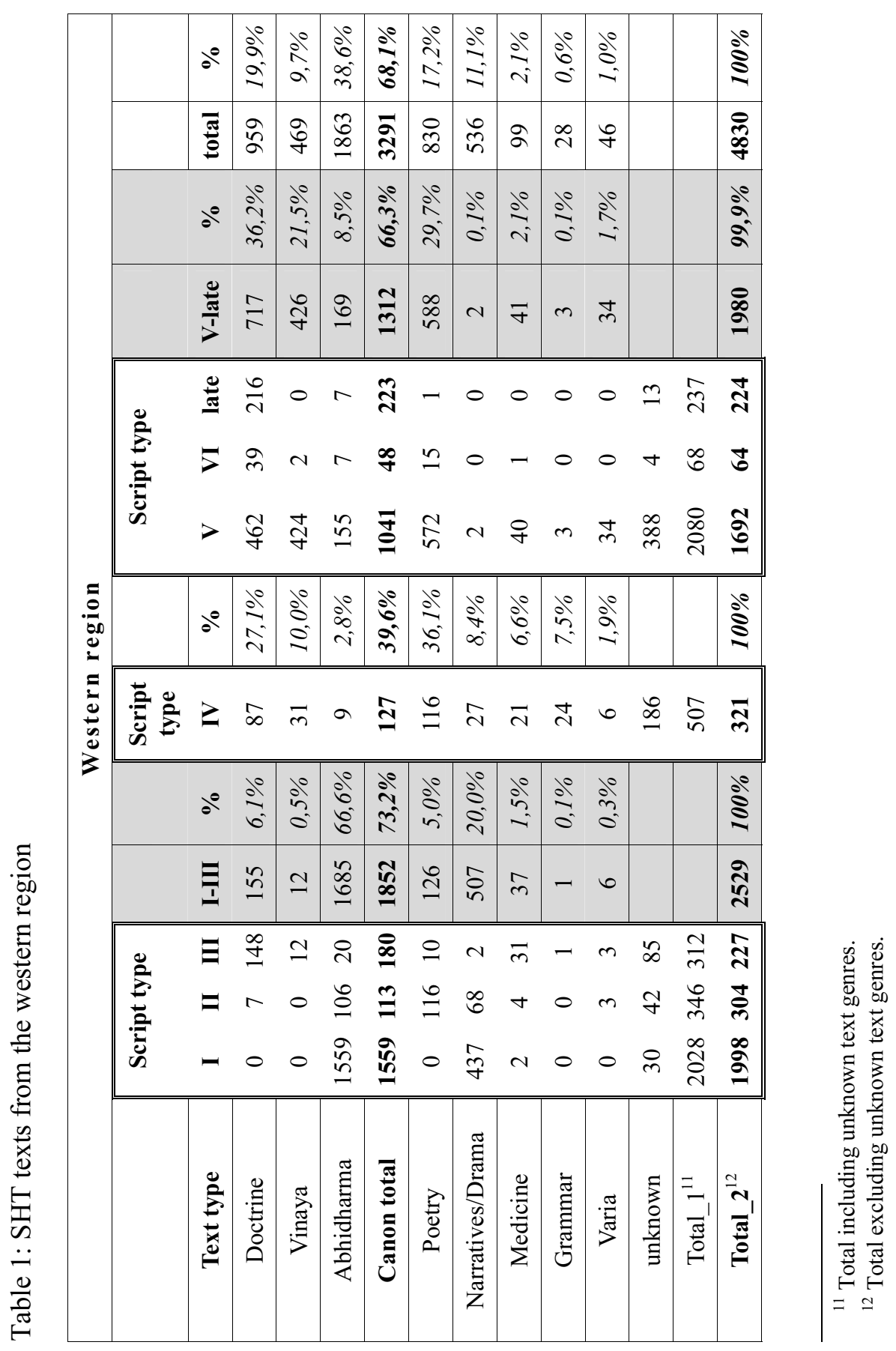




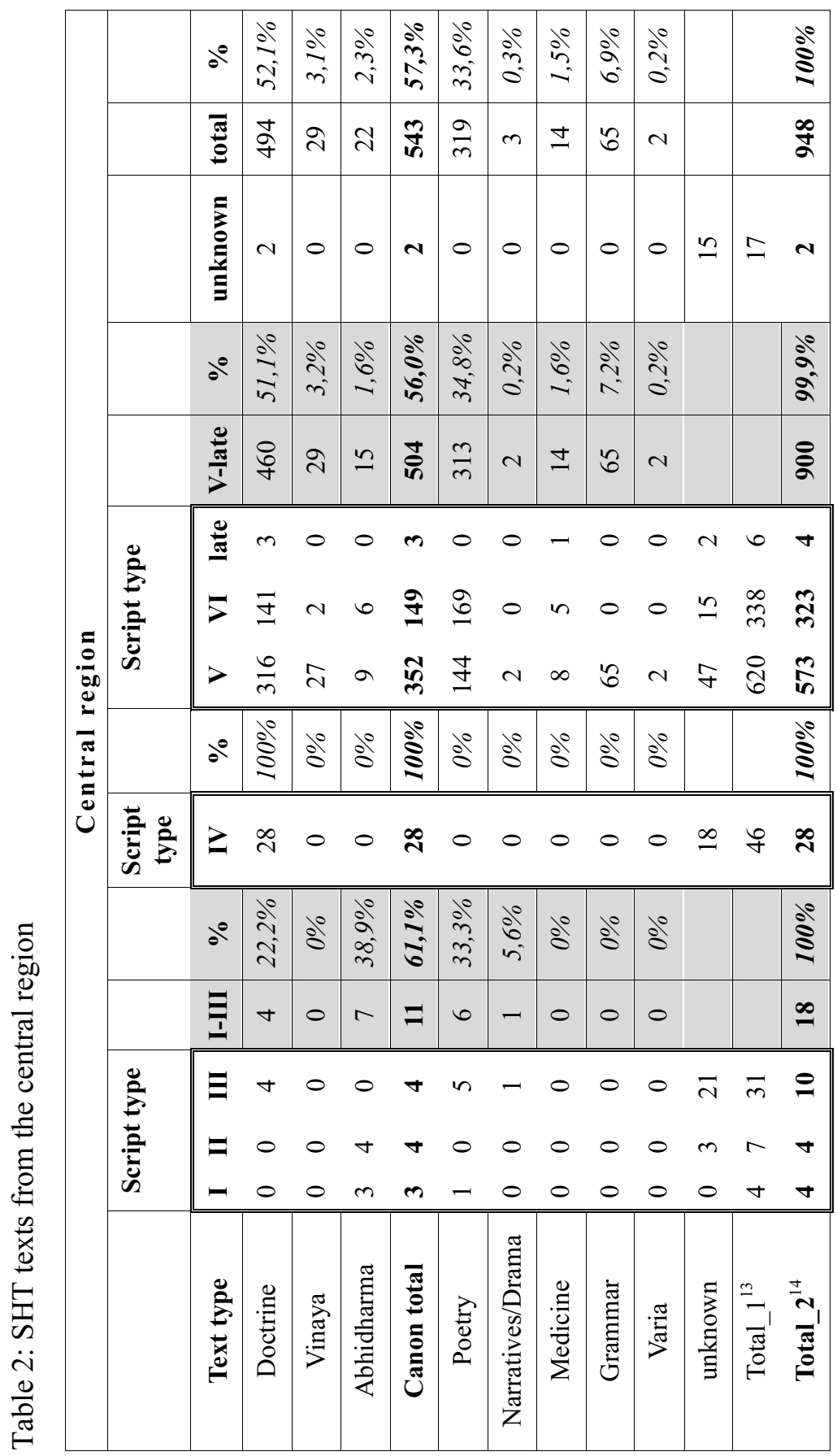

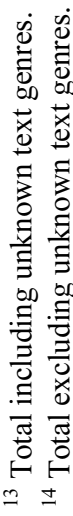




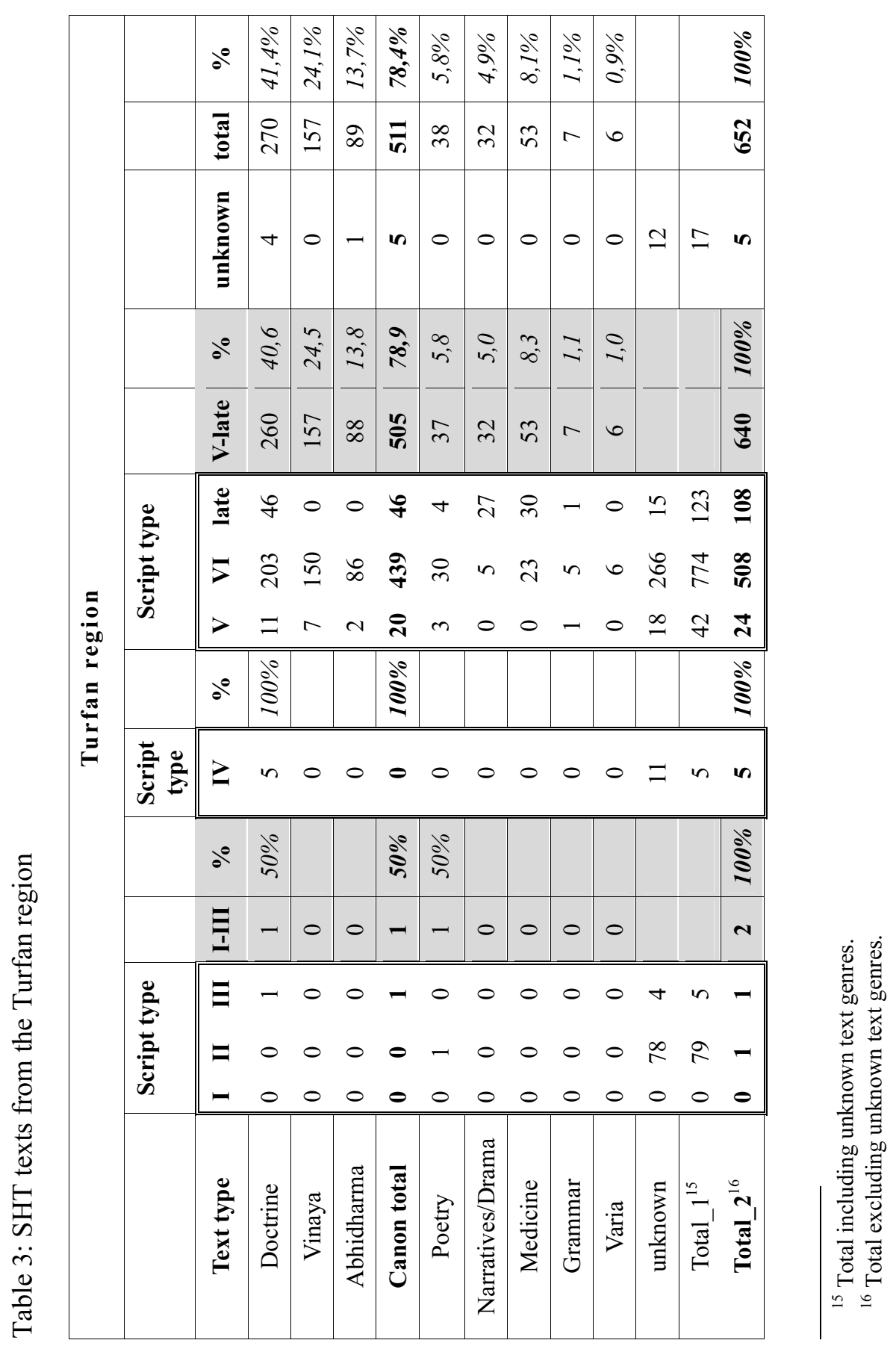




\begin{tabular}{|c|c|c|c|c|c|c|c|c|c|c|c|c|c|c|c|}
\hline \multirow{13}{*}{ 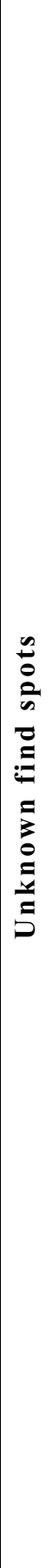 } & & $\partial^{0}$ & $\begin{array}{l}\frac{2}{2} \\
\frac{3}{3}\end{array}$ & $\begin{array}{l}80 \\
6 \\
0^{\circ}\end{array}$ & $\begin{array}{l}80 \\
= \\
=\end{array}$ & $\begin{array}{l}\partial \\
\infty \\
\hat{n}\end{array}$ & $\begin{array}{l}\text { aे } \\
2 \\
2\end{array}$ & $\frac{d^{\circ}}{d}$ & $\overrightarrow{\hat{i}}^{\circ}$ & $\frac{d}{0}$ & $\stackrel{一}{2}$ & & & & $\stackrel{8}{8}$ \\
\hline & & 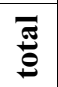 & $\stackrel{q}{q}$ & $\bar{\sim}$ & $\bar{m}$ & $\hat{\infty}$ & $\overline{\widetilde{N}}$ & $\widehat{\imath}$ & $\bar{m}$ & $\nabla$ & $J$ & & & & $\stackrel{m}{\Xi}$ \\
\hline & & 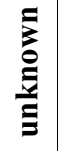 & $m$ & - & 0 & $\nabla$ & $\infty$ & 0 & 0 & 0 & $c$ & & $\stackrel{\infty}{n}$ & 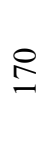 & $\simeq$ \\
\hline & & $\partial^{0}$ & $\begin{array}{l}\infty \\
i \\
i\end{array}$ & $\begin{array}{l}m \\
\stackrel{n}{v}\end{array}$ & 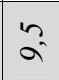 & $\begin{array}{l}0 \\
i\end{array}$ & $\begin{array}{l}b \\
\therefore\end{array}$ & $\begin{array}{l}\infty \\
i\end{array}$ & $\tilde{v}$ & $\stackrel{n}{0}$ & - & & & & 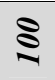 \\
\hline & & $\frac{\frac{\pi}{\pi}}{\frac{\pi}{1}}$ & $\frac{0}{7}$ & $\stackrel{\infty}{=}$ & $\alpha$ & $\stackrel{2}{2}$ & 유 & $\grave{v}$ & $\stackrel{\beth}{\sim}$ & $m$ & I & & & & 朵 \\
\hline & $\sum_{0}^{0}$ & $\begin{array}{l}\frac{\tilde{E}}{5} \\
5\end{array}$ & $\begin{array}{l}\circ \\
\stackrel{0}{\sim} \\
\stackrel{\circ}{N}\end{array}$ & $\begin{array}{l}0 \\
\text { 卞 }\end{array}$ & $\begin{array}{l}\sim \\
\infty\end{array}$ & $\begin{array}{l}\approx \\
\bar{q}\end{array}$ & n & $\vec{\sim}$ & $\begin{array}{l}\circ \\
\stackrel{৩}{ }\end{array}$ & - & $c$ & & $\begin{array}{l}\stackrel{8}{0} \\
\underset{m}{\text { Fे }}\end{array}$ & $\begin{array}{l}n \\
\stackrel{n}{n} \\
\stackrel{n}{n}\end{array}$ & $\begin{array}{l}n \\
\stackrel{\infty}{\circ} \\
\stackrel{8}{n}\end{array}$ \\
\hline & 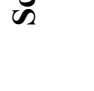 & $>$ & $\stackrel{n}{n}$ & $\stackrel{q}{q}$ & $\nabla$ & 气ิ & I & 6 & $\nabla$ & 0 & $\subseteq$ & & in & & 官 \\
\hline & & $\partial^{0}$ & $\frac{d{ }^{0}}{\infty^{\circ}}$ & $\begin{array}{l}\text { di } \\
\text { in } \\
2\end{array}$ & $\frac{d}{\stackrel{0}{0}}$ & $\frac{a}{i}$ & $\begin{array}{l}\text { ¿ें } \\
\text { cे }\end{array}$ & $\mathrm{g}^{\circ}$ & $\begin{array}{l}\text { iे } \\
a^{2}\end{array}$ & $8^{\circ}$ & हो & & & & 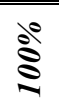 \\
\hline & 节 & $\geq$ & $\stackrel{F}{+}$ & 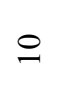 & - & in & $\simeq$ & 0 & $r$ & 0 & . & & $\stackrel{\infty}{\infty}$ & $\tilde{n}$ & $\mathbb{N}$ \\
\hline & & $\partial^{0}$ & $\begin{array}{l}\text { do } \\
\text { jे } \\
7\end{array}$ & $\begin{array}{l}d 0 \\
i\end{array}$ & $\begin{array}{l}\frac{0}{2} \\
\hat{n} \\
i\end{array}$ & $\begin{array}{l}d 0 \\
\hat{a} \\
\hat{a}\end{array}$ & $\dot{m}_{-}^{\circ}$ & $8^{\circ}$ & $\delta^{\circ}$ & $i$ & 8 & & & & $\begin{array}{l}\partial^{\circ} \\
\hat{a}\end{array}$ \\
\hline & & $\Xi$ & $m$ & $N$ & $\underset{m}{\infty}$ & $\approx$ & - & 0 & 0 & - & $c$ & & & & $\mathfrak{r}$ \\
\hline & 总 & $\begin{array}{l}\Xi \\
\equiv \\
\end{array}$ & $\begin{array}{l}m \\
0 \\
0\end{array}$ & $\begin{array}{l}- \\
- \\
0\end{array}$ & $\begin{array}{l}\underset{J}{J} \\
0 \\
\Xi\end{array}$ & $\begin{array}{l}\infty \\
- \\
- \\
\square\end{array}$ & $\begin{array}{l}- \\
0 \\
0\end{array}$ & $\begin{array}{l}0 \\
0 \\
0\end{array}$ & $\begin{array}{l}0 \\
0 \\
0\end{array}$ & $\begin{array}{l}- \\
0 \\
0\end{array}$ & $c$ & & $\begin{array}{l}\Xi \\
\cong \\
\cong \\
-\end{array}$ & 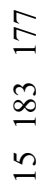 & $\begin{array}{l}8 \\
- \\
\pm\end{array}$ \\
\hline & & 窇 & 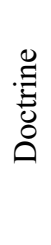 & 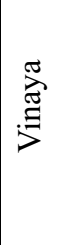 & 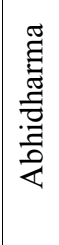 & 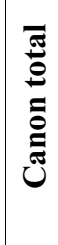 & 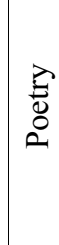 & 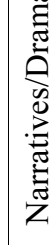 & $\begin{array}{l}\frac{\mathbb{Z}}{0} \\
: \frac{0}{0} \\
\sum\end{array}$ & 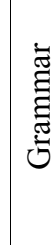 & 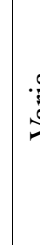 & & $\begin{array}{l}\text { है } \\
0 \\
\Xi \\
\Xi\end{array}$ & 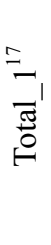 & 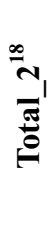 \\
\hline
\end{tabular}

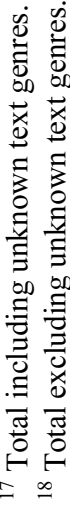




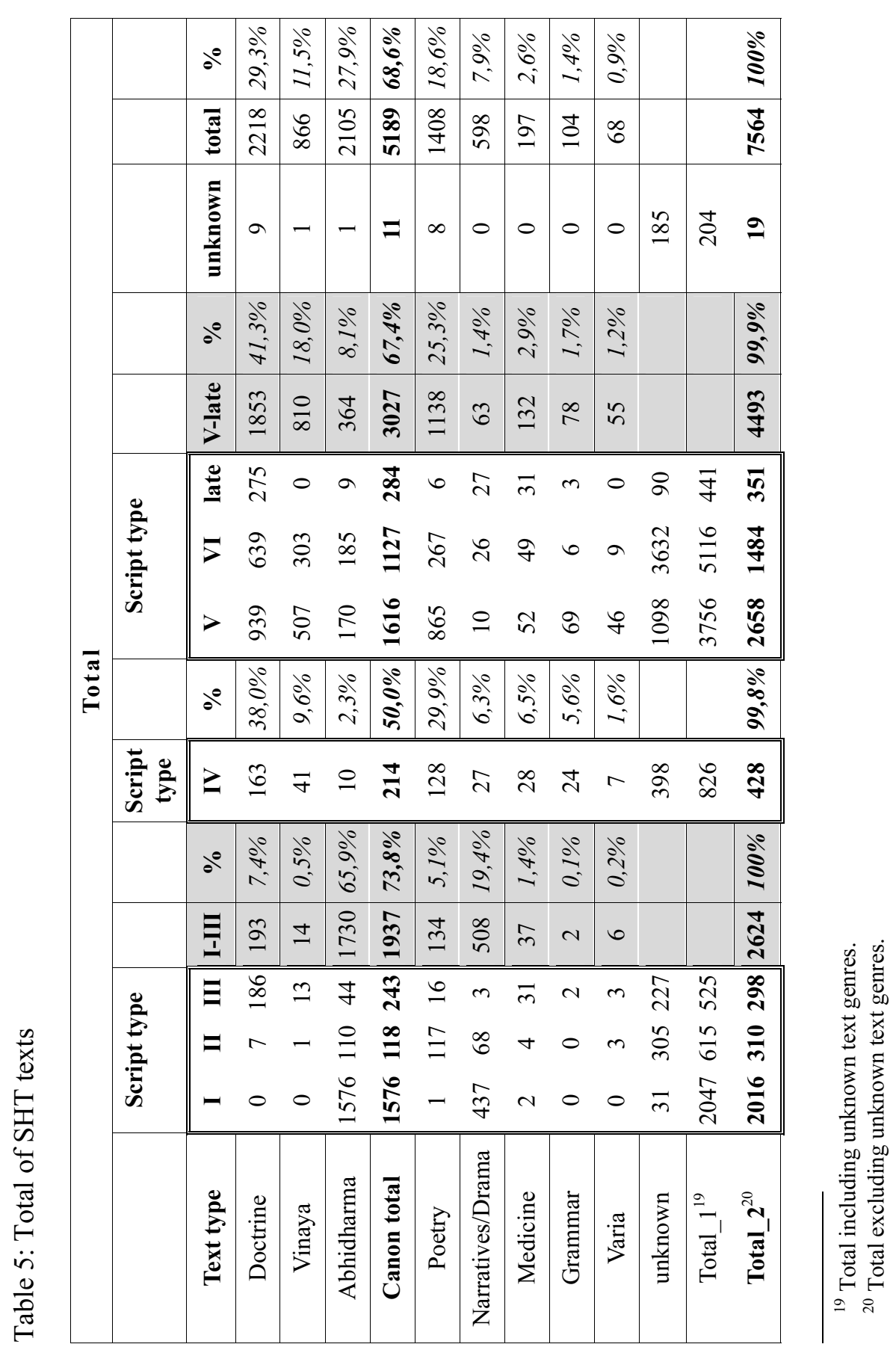




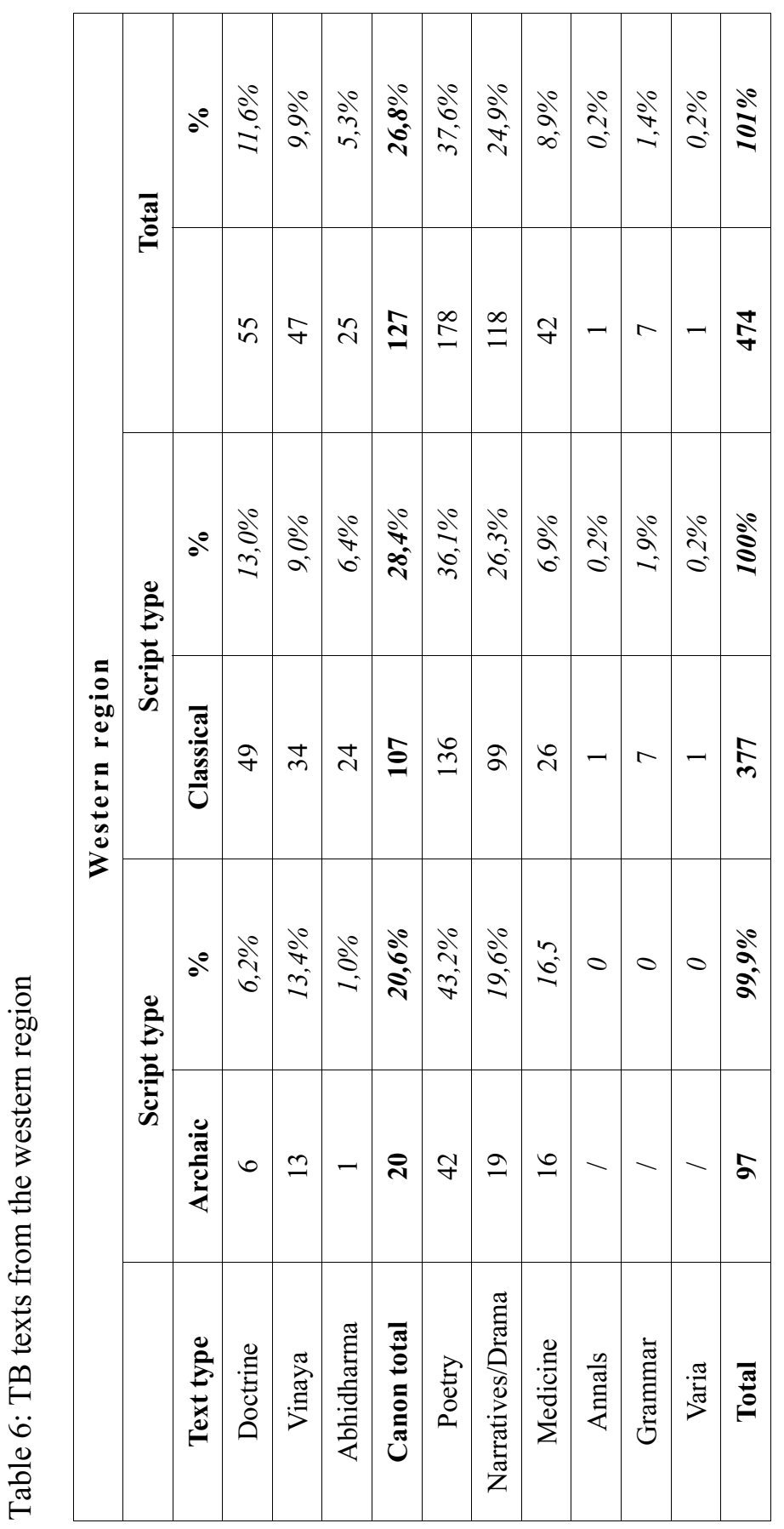




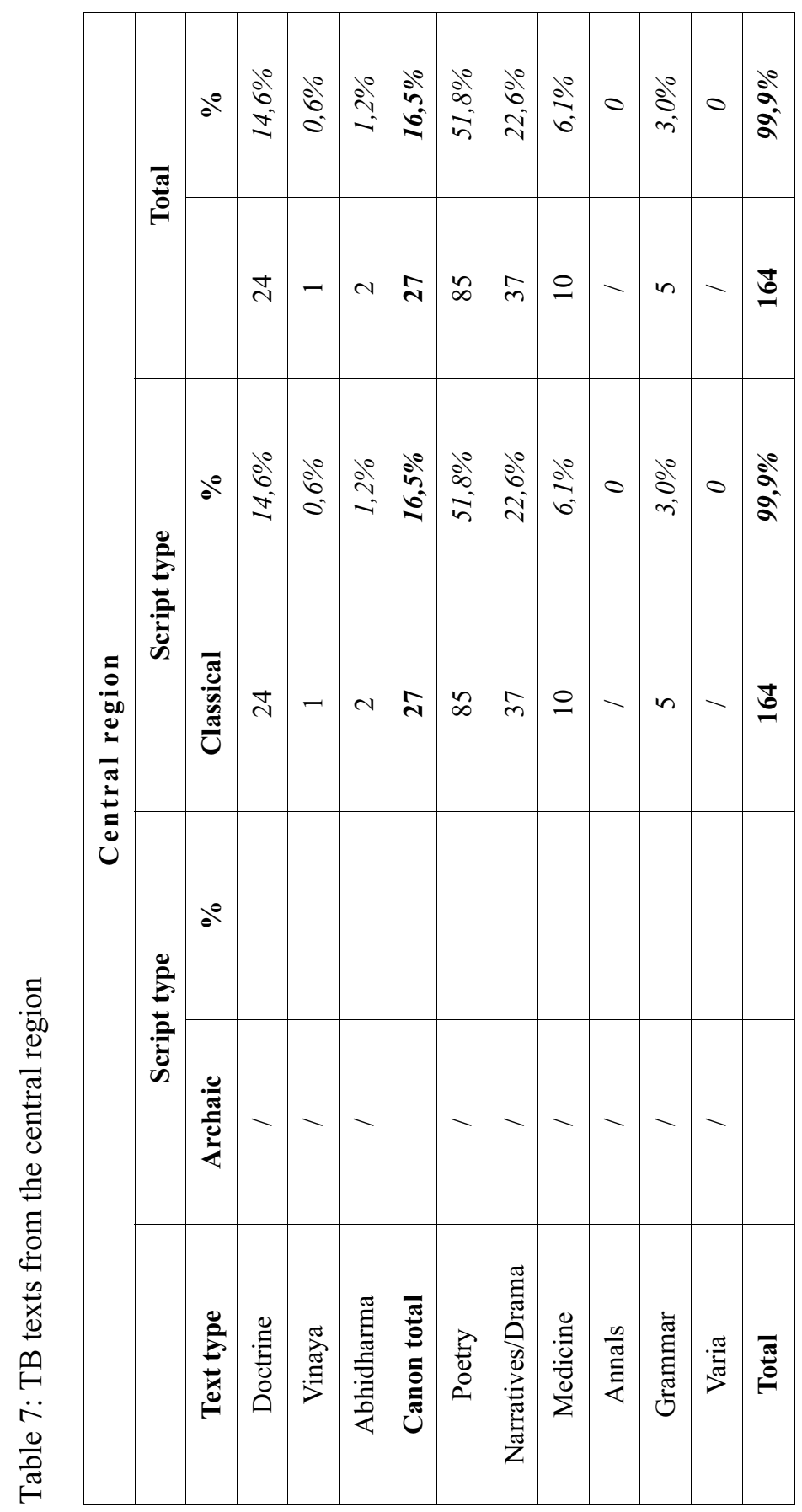




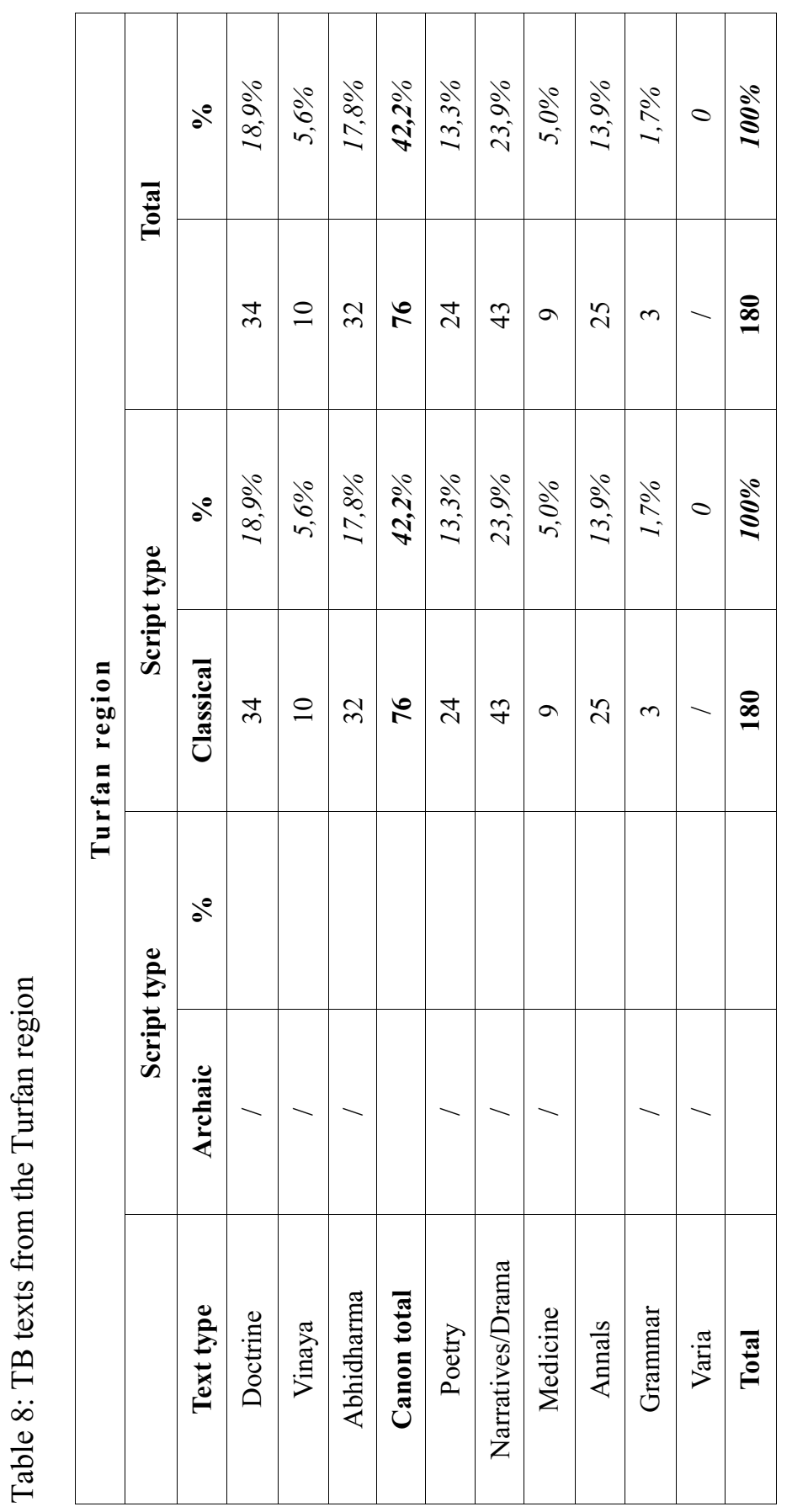




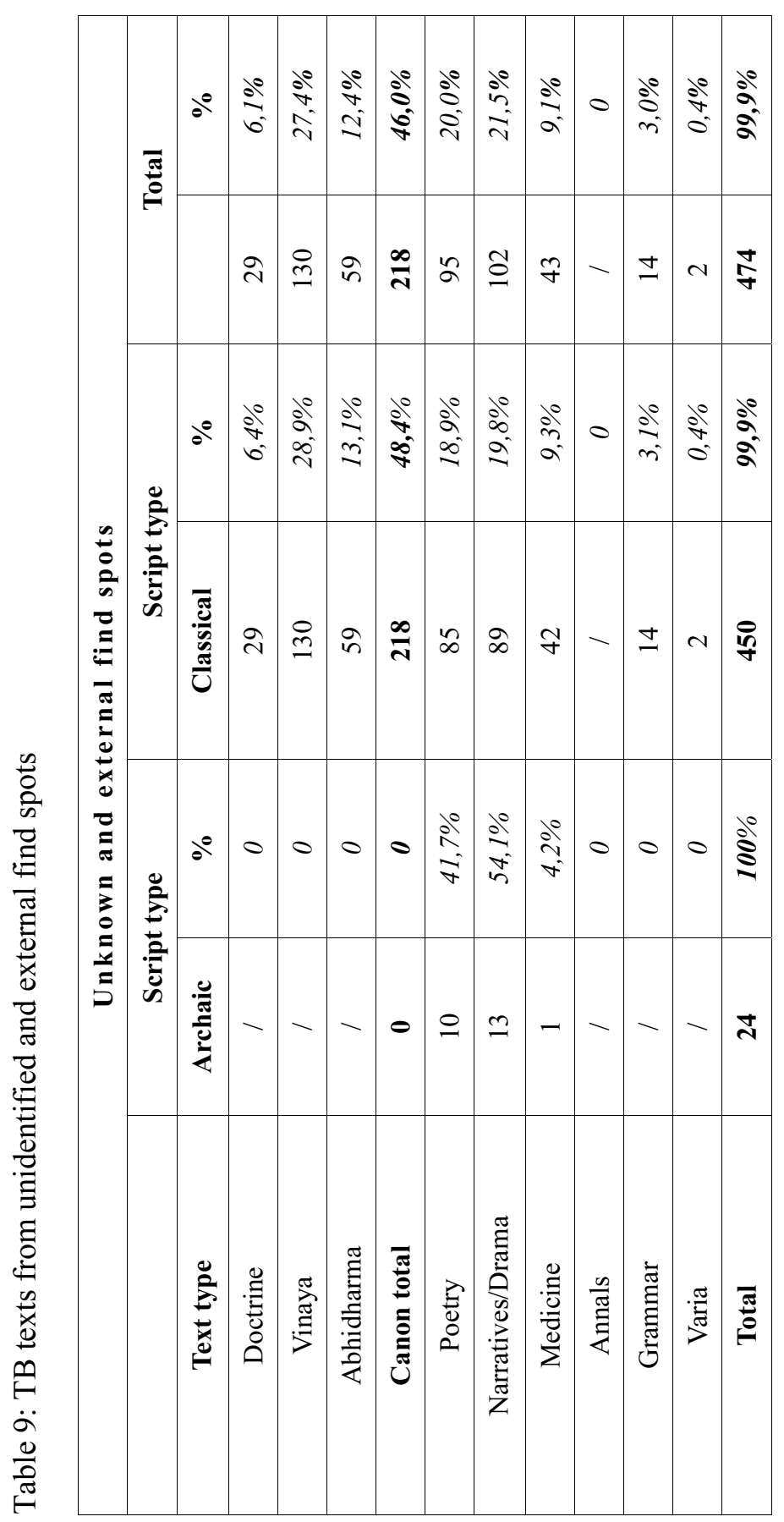




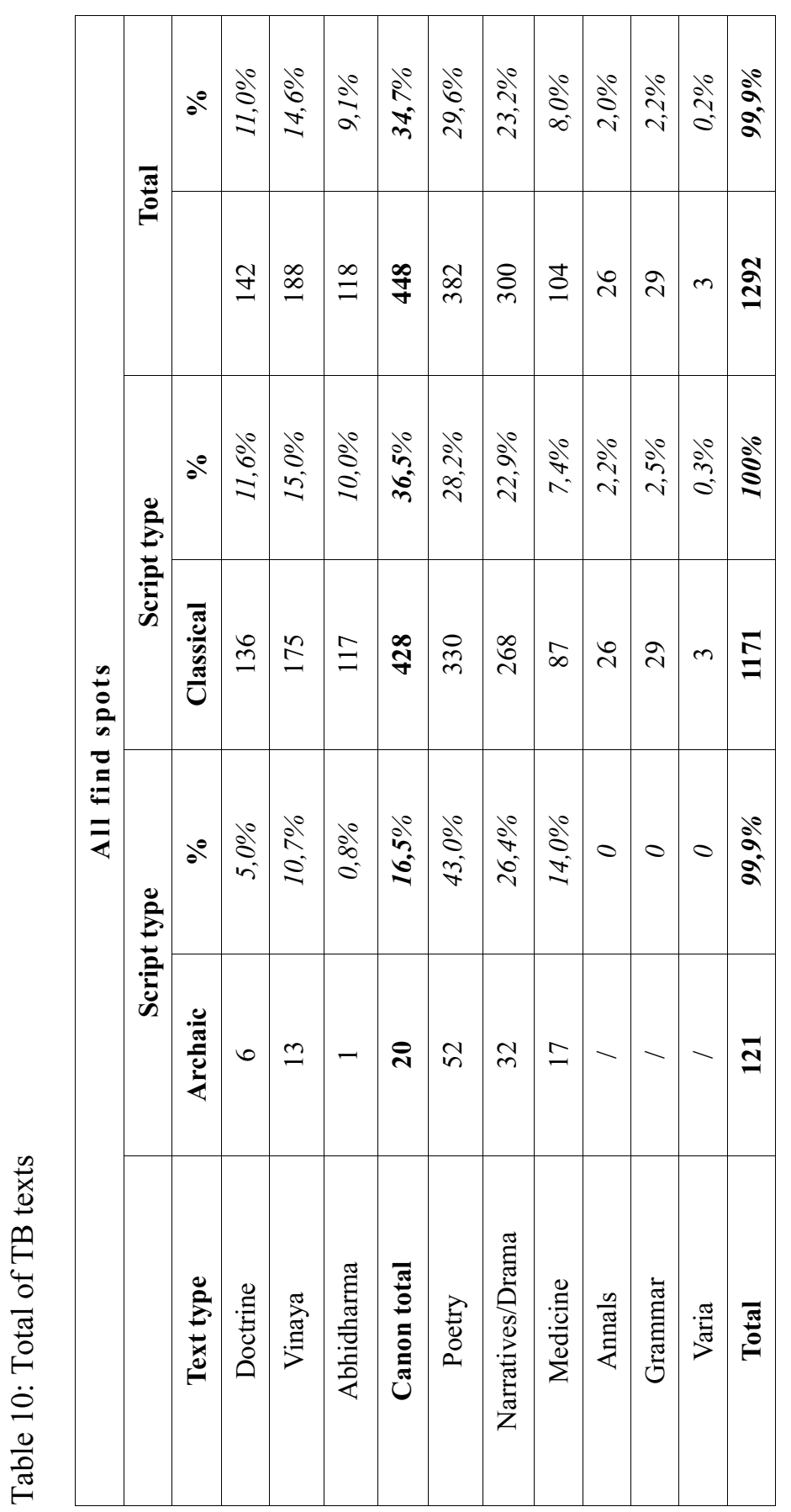




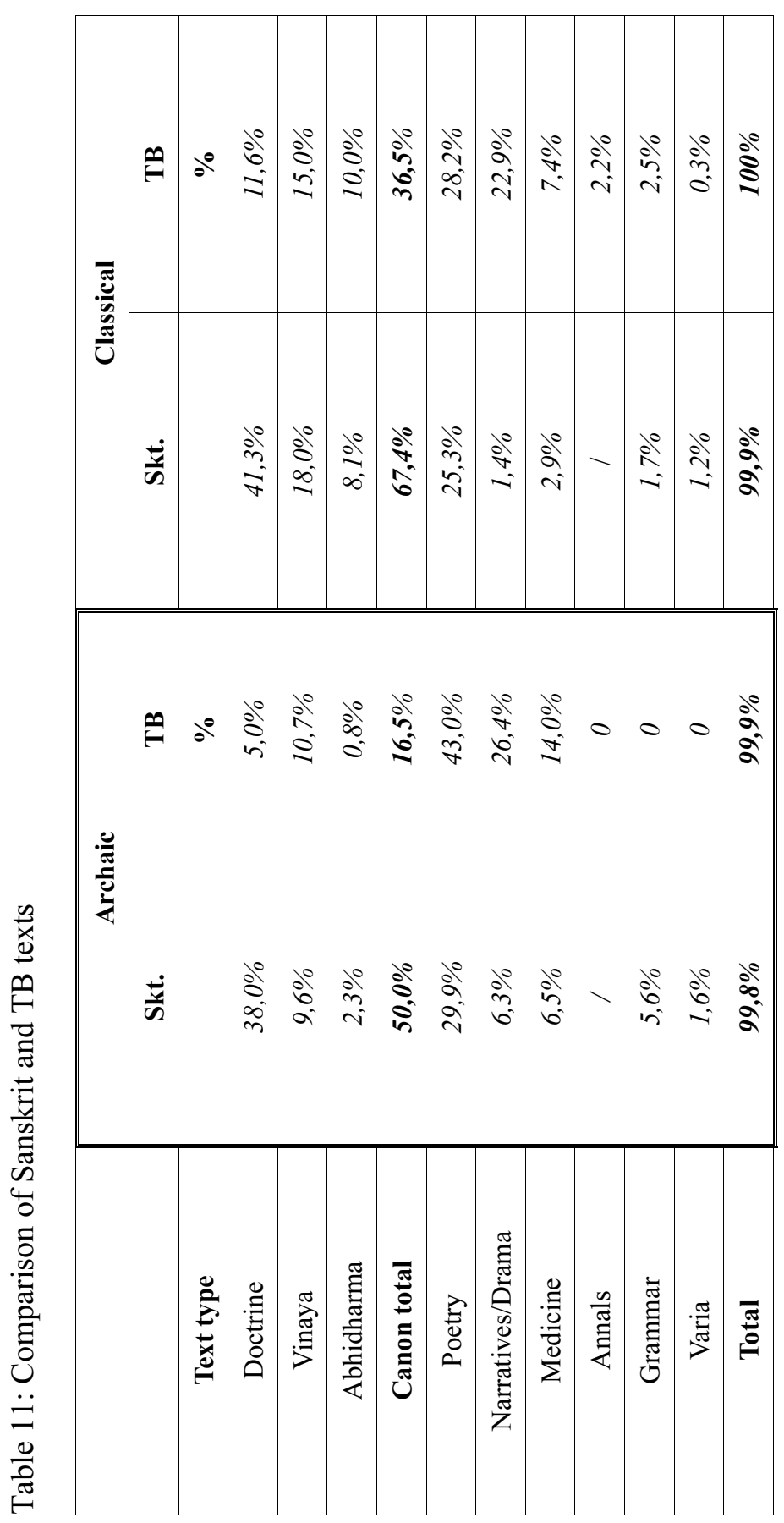




\section{Statistical analysis ${ }^{21}$}

The survey reveals that in general, Tocharian and Sanskrit text genres show roughly the same distribution with two notable exception. The data is reliable because a statistic analysis makes it likely that the distribution of text genres is not due to chance: the $p$-value for the archaic period is $<.00$, the effect size significant $(\varphi=.406)$, the more for the classical period $(\mathrm{p}<.001$ and $\varphi=.448)$, see table 12 .

Table 12: Percentual distribution of the frequency rate by text genres

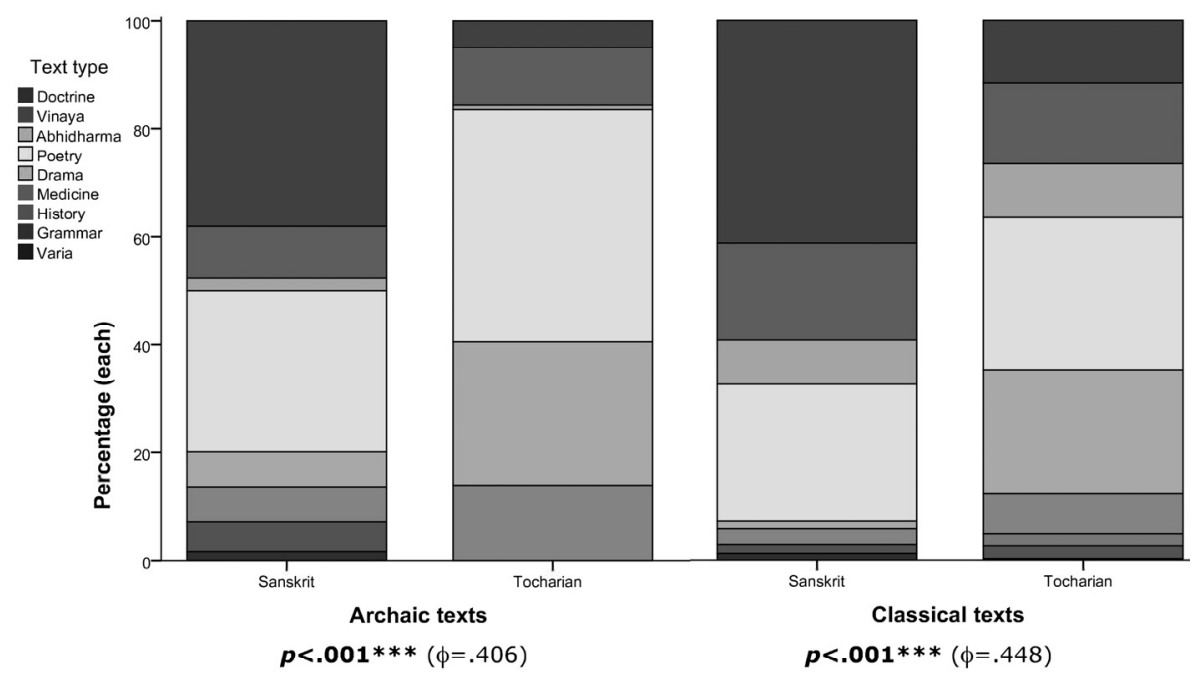

On average, around two thirds of Sanskrit fragments belong to canonical texts; in the earliest period (western region script Types I-III) this proportion is even higher with $73.8 \%$. In contrast, the proportion of canonical texts in TB is usually lower, especially in the western region $(21.7 \%$ in the earlier and $36.0 \%$ in the classical period). Interestingly enough, this disproportion is mostly due to doctrinal texts, while the number of Vinaya and Abhidharma texts is somewhat constant and evenly distributed: TB Vinaya $10.7 \%$ (Archaic period) and 14.6\% (classical period) beside Sanskrit Vinaya 9.6\% (script Type IV) and 18\% (classical period); TB Abhidharma $0.8 \%$ (Archaic period) and $10 \%$ (classical period) beside Sanskrit Abhidharma is 2.3\%

\footnotetext{
${ }^{21}$ I would like to thank Marik Roos for his kind help with the statistical analysis.
} 
(script Type IV) and $8.1 \%$ (classical period). On the other hand, there is a clear predominance of para-canonical in Tocharian B. Again, this distribution is not due to chance $(\mathrm{p}<.000$ and $\varphi=.452)$, and interestingly enough the statistical parameter is roughly the same for the archaic and classical corpus (see table 13).

Table 13: Percentual distribution of the frequency rate of canonical and para-canonical texts

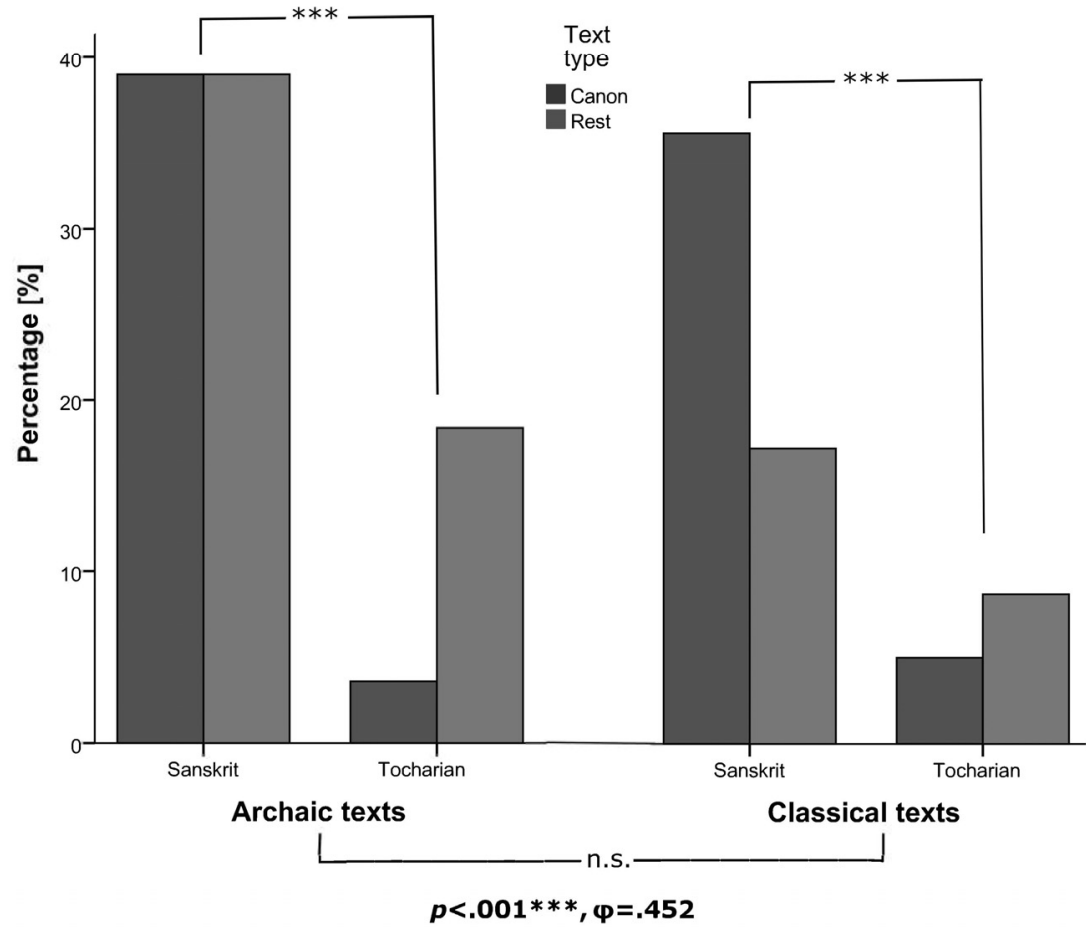

This result is actually not too surprising, because one may safely assume that - especially at the beginning of TB vernacular writing - doctrinal texts were mostly still used in the Sanskrit original while the translation of paracanonical literature and scientific texts was more important to the communities. $^{22}$ See also PEYrot 2017 who shows that "the speakers of Tocharian

${ }^{22}$ Note that one of the most archaic TB manuscript is actually a medical one; see MALZAHN 2007, 267 and 274: here belong THT 2618, THT 2668, THT 2669, THT 2670, THT 2671, THT 2672, THT 2673, THT 2676, THT 2677, THT 3209, THT 3211, and THT 4122. 
preferred the Udānavarga in Sanskrit", while only the commentary text Udānālañkāra "became popular in Tocharian".

What is striking, and that even from a statistical point of view, is the disproportion of narrative/drama texts in Tocharian, the more in the classical period. There are far more narrative/drama texts in Tocharian in the classical period in relation to the archaic period than can be due to mere chance $\left(\chi^{2}=20.154 ; \mathrm{p}<.000 ; \varphi=.227\right)$.

In contrast, the number of Sanskrit narrative/drama texts is usually very low with the notable exception of the earliest period (western region, script Types I-III) with $20 \%$. Among these very early texts, we find the so far only example of a drama text proper in the Turfan Sanskrit corpus, namely the very early fragments of plays by Aśvaghoșa dated into the 2 nd c. ${ }^{23}$ In the later Sanskrit corpus, there is some evidence of narrative literature (Jātakas and Avadānas), but no play proper. ${ }^{24}$

The case of poetry (Buddhastotras, Kāvyas) is different. They actually constitute the majority of texts in the earliest TB period (in total 43\%). During the classical period, the numbers of poetry fragments is even in TB and Sanskrit (28.2\% and 25.3\%), in the archaic period the number in TB is higher (43\%), but, in Sanskrit, $29.9 \%$ is still a high number; this contrast, however, is statistically not relevant $\left(\chi^{2}=3.699 ; \mathrm{p}=.054\right)$, so one can say that there is no notable difference in the production/writing of poetic literature in both languages and periods.

Apart from the statistics presented here, there are other facts that speak in favor of notacible popularity of Buddhist narratives and their respective plays in the Tocharian culture. This is clear from numerous wall paintings in Buddhist sites that depict jātaka and avādana scenes and which are regularly accompanied by captions informing the onlooker on the precise setting of the depicted scene. ${ }^{25}$ The popularity of Tocharian drama can finally be concluded from its role in the development of the Chinese bianwen genre. ${ }^{26}$

The fact that there is a mismatch between the popularity of narrative literature in Tocharian and the simultaneous scarcity of respective Sanskrit texts has already been noted by scholars before ${ }^{27}$ and it has puzzled scholars

${ }^{23}$ LÜDERS 1911.

${ }^{24}$ That Sanskrit plays were read in the later period outside India is proven by the fragment of a play found in Afghanistan dated into the 6th century (FrANCO/SCHLINGLOFF 2012). See also PinAUlt 2016: 174 and 2017: 479.

${ }^{25}$ PinAUlt 2000; ARlt and Hiyama 2015.

${ }^{26}$ MAIR 1988 and 1989; PINAUlt 1989: 205-212.

${ }^{27}$ Most recently PinAULT 2017: 479. 
for some time. The famous problem about the missing Indic original referred to in the Old Turkic version of the TA Maitreyasamiti-Nātaka is a case in point. The statistics presented above now shows beyond doubt that there is a clear mismatch and that this mismatch can be narrowed down to narratives/dramas and does not concern poetry in general or other genres of para-canonical literature.

One solution to account for this fact has been to assume that the respective Sanskrit originals of plays and narratives have simply been lost. However, the statistics presented above highly speak against such an assumption. We rather have to conclude that neither as many narratives nor dramaturgic adoptions of narrative texts did ever exist in written form in Sanskrit to serve as direct models of Tocharian narrative/dramatic literature. The next obvious idea would be to assume a high proportion of oral literature in the narrative/drama genre. But it is difficult to find a reason why it was precisely Sanskrit narratives/dramas that were part of a vivid oral tradition in Turkestan ${ }^{28}$ but not written down while their Tocharian translations were, when, in contrast, in the case of poetry there is an even distribution of Sanskrit and Tocharian texts.

On the other hand, the TB and TA literary and poetic language is in general based on the Buddho-Indian model, and this is basically also true for the story lines and stylistics of narratives. Many narratives attested in Tocharian are known from parallel texts in other Buddhist languages (Pāli, Sanskrit, Sogdian, Khotanese Saka, Tibetan, Chinese); in several detailed studies (see esp. PINAUlT 2014, 2015a, 2016 and 2017), Georges-Jean Pinault has shown how Indo-Buddhist literary techniques were adapted in Tocharian, precisely with respect to the narrative/dramatic genre. This ranges from the term TA/TB nātak borrowed from Sanskrit nātaka- 'play', dramaturgic elements and structuring (prose/verse alternating campu $\bar{u}$ style, schematic characters such as the female door warden, etc.) to the adaption of Sanskrit phrases and key terms. The detailed study by PINAULT 2015a on calques, for instances, shows the creativity of Tocharian writers when transporting terms, concepts and phraseology into their vernacular.

The most likely explanation for the prevalence of Tocharian vernacular narrative and dramatic literature, in my opinion, lies in the assumption of an inner-Tocharian development (see also PINAULT 2015b: 589). This is

${ }^{28}$ SKJAERVO 2009: 207 points out that the characteristics of oral performance was recomposition, "poets and performers of old [...] always produce a new song or tale, one that has not been heard before". 
supported by the fact that, whenever we do have a parallel for a narrative in another language, in most cases the Tocharian version differs, and very often the Tocharian text is characterized by more detail and lavish dialogues (see, e.g., PINAUlT 2015). Most certainly the display of narratives and dramatic scenes was an effective way to make Buddhist teachings and ethics known to the general public and to laypersons (see also PINAULT 2015b: 584). This is in accordance with the statistic analyses since it is in the earliest period of Sanskrit texts, i.e. in the pre-vernacular period that the highest percentage of narratives/plays is attested: alongside the canon, narratives and plays were imported to spread the Buddhist faith. Once the Tocharian vernacular came into use as a literary language for Buddhism, the narrative genre was further developed for the same reason.

In this way one may also explain the differences between Tocharian and Sanskrit stylistics, the most notable being the meter. It is clear that the poetic TB language was developed in the earliest period of writing, i.e., in the archaic period. This is, for instance, clear from the verse colometry that follows the phonology of archaic TB. ${ }^{29}$ Use and adaption of pre-Buddhist stylistic and performing arts ${ }^{30}$ must certainly have been another way to make the Buddhist teachings more appealing to the general public as well.

Future research will have to discern more details about the adaption of Indo-Buddhist models of narrative/dramatic literature and their inner-Tocharian development and about whether one can detect (more) pre-Buddhist/ Indo-Buddhist literary/poetic devices.

\author{
Abbreviations \\ CEToM: A Comprehensive Edition of Tocharian Manuscripts. \\ SHT: Sanskrithandschriften aus den Turfanfunden. \\ THT: Tocharische Handschriften aus den Turfanfunden. \\ TA: Tocharian A. \\ TB: Tocharian B.
}

${ }^{29}$ See MALZAHN 2012 and Malzahn in print.

${ }^{30}$ It is clear that music and performing arts and artists played an important role in the (Buddhist) Tocharian culture, as can be deduced from paintings, the mentioning of music and performing arts in the texts themselves as part of court life and also from TB business documents concerning the remuneration of musicians by a monastery (PK DA M 507.7 a 10 and PK DA M 507.42 and .40 a 11; for the texts see PINAUlt 1994: 94 and 102, 104; for the text PK LC 10 see PinAUlt 2008: 380-395). 


\section{References}

ARLT, Robert and HIYAMA Satomi 2015: "Theatrical figures in the mural paintings of Kucha". Journal of the International Association of Buddhist Studies 38, 313-348.

FrANCO, Eli and Schlingloff, Dieter 2012: Zu dem buddhistischen Schauspielfragment aus Afghanistan. Wiener Zeitschrift für die Kunde Südasiens 54, 19-33.

LÜDERS, Heinrich 1911: Bruchstücke buddhistischer Dramen. Berlin: Reimer (Königlich Preussische Turfan-Expeditionen. Kleinere Sanskrit-Texte, Heft 1).

MAIR, Victor H. 1988: Painting and Performance. Chinese picture recitation and its Indian genesis. Honolulu: University of Hawaii Press.

MAIR, Victor H. 1989: T'ang Transformation Texts. A study of the Buddhist contribution to the rise of vernacular fiction and drama in China. Cambridge (Mass.): Harvard-Yenching Institute.

Malzahn, Melanie 2007: The most Archaic Manuscripts of Tocharian B and the Varieties of the Tocharian B Language, In: Malzahn, Melanie, ed., Instrumenta Tocharica. Heidelberg: Winter, 255-297.

MalZAhN, Melanie 2012: Now you see it, now you don't-Bewegliches -o in Tocharisch B. In Hackstein, Olav and Ronald Kim (eds.), Linguistic developments along the Silk Road: Archaism and Innovation in Tocharian. Wien: Verlag der ÖAW, 33-82.

MALZAHN, Melanie in print: Lautliche Aspekte tocharischer Dichtersprache. In Language and Meter.

PeYrot, Michaël 2017: The Sanskrit Udānavarga and the Tocharian B Udānastotra: a window on the relationship between religious and popular language on the northern Silk Road. Bulletin of the School of Oriental and African Studies 79/2, 305-327.

PinAUlt, Georges-Jean 1989: Une version koutchéenne de l'Aggañña-Sutta. Tocharian and Indo-European Studies 3, 149-220.

Pinault, Georges-Jean 1994: Aspects du bouddhisme pratiqué au nord du désert du Taklamakan, d'après les documents tokhariens. In: Fukui, Fumimasa and Gérard Fussman, eds., Bouddhisme et cultures locales. Quelques cas de réciproques adaptations. Actes du colloque franco-japonais de septembre 1991. Paris: École française d'Extrême-Orient, 85113.

PINAULT, Georges-Jean 2000: Narration dramatisée et narration en peinture dans la région de Kucha, In Drège, Jean-Pierre, ed., La Sérinde, terre d'échanges. Art, religion, commerce du Ier au Xe siècle. Actes du colloque international (Galeries nationales du Grand Palais, 13-15 février 1996). Paris: La Documentation française (XIVes rencontres de l'Ecole du Louvre), 149-168.

PINAULT, Georges-Jean 2008: Chrestomathie tokharienne. Textes et Grammaire. Leuven/ Paris: Peeters.

PINAUlt, Georges-Jean 2014: Buddhist stylistics in Central Asia, In García Ramón, José Luís and Daniel Kölligan, eds., Strategies of translation: language in contact, poetic language. Roma: Fabrizio Serra, 89-107.

PINAULT, Georges-Jean 2015: The legend of the unicorn in the Tocharian version. Journal of the International Association of Buddhist Studies 38, 191-222.

PINAULT, Georges-Jean 2015a: The formation of Buddhist languages, as exemplified by the Tocharian evidence, In: Malzahn, Melanie et al., eds., Tocharian Texts in Context. International Conference on Tocharian Manuscripts and Silk Road Culture held June 2628, 2013 in Vienna. Bremen: Hempen, 159-185. 
PinAult, Georges-Jean 2015b: Dramatic works: Central Asia. In ed. J. Silk et al., Brill's Encyclopedia of Buddhism. Vol. I: Literature and languages, Leiden/Boston: Brill, 584-590.

PINAULT, Georges-Jean 2016: Les Tokhariens, passeurs et interprètes du bouddhisme, In Espagne, Michel, Svetlana Gorshenina, Frantz Grenet, Shahin Mustafayev and Claude Rapin, eds., Asie Centrale. Transferts culturels le long de la Route de la Soie. Paris: Vendémiaire, 167-200.

PINAULT, Georges-Jean 2017: Theatre jargon and literary language in Tocharian, In: Turfanforschung, ed., Zur lichten Heimat. Studien zu Manichäismus, Iranistik und Zentralasienkunde im Gedenken an Werner Sundermann. Wiesbaden: Harrassowitz, 511-524.

SANDER, Lore 1968: Paläographisches zu den Sanskrithandschriften der Berliner Turfansammlung. Wiesbaden: Franz Steiner.

SANDER, Lore 2013: Was kann die Paläographie zur Datierung tocharischer Handschriften beitragen?, In: Kasai, Yukiyo, Abdurishid Yakup, and Desmond Durkin-Meisterernst, eds., Die Erforschung des Tocharischen und die alttürkische Maitrisimit. Turnhout: Brepols (Silk Road Studies 17), 277-324.

SANDER, Lore and WALDSCHMIDT, Ernst 1980: Sanskrithandschriften aus den Turfanfunden. Teil 4. Ergänzungsband zu Teil 1-3 mit Textwiedergaben, Berichtigungen und Wörterverzeichnissen. Wiesbaden: Steiner (Verzeichnis der orientalischen Handschriften in Deutschland 10, 4).

SANDER, Lore and WALDSCHMIDT, Ernst 1985: Sanskrithandschriften aus den Turfanfunden. Teil 5. Die Katalognummern 1015-1201 und 63 vorweggenommene höhere Nummern. Wiesbaden: Steiner (Verzeichnis der orientalischen Handschriften in Deutschland 10, 5).

SkJAervo, Prods Oktor 2009: Reflexes of Iranian oral tradition in Manichean literature, In: Durkin-Meisterernst, Desmond, Christiane Reck and Dieter Weber, Literarische Stoffe und ihre Gestaltung in mitteliranischer Zeit. Kolloquium anlässlich des 70. Geburtstages von Werner Sundermann. Wiesbaden: Reichert, 269-286.

TAMAI, Tatsushi 2011: Paläographische Untersuchungen zum B-Tocharischen. Innsbruck: Institut für Sprachen und Literaturen (Innsbrucker Beiträge zur Sprachwissenschaft 138).

WaLDSCHMidT, Ernst 1965: Sanskrithandschriften aus den Turfanfunden. Teil 1. Die Katalognummern 1-801. Unter Mitarbeit von Walter Clawiter und Lore Holzmann. Wiesbaden: Franz Steiner Verlag (Verzeichnis der orientalischen Handschriften in Deutschland $10,1)$.

WaLDSCHMIDT, Ernst 1968: Sanskrithandschriften aus den Turfanfunden. Teil II. FaksimileWiedergaben einer Auswahl von Vinaya- und Sūtrahandschriften nebst einer Bearbeitung davon noch nicht publizierter Stücke. Im Verein mit Walter Clawiter und Lore SanderHolzmann. Wiesbaden: Steiner (Verzeichnis der orientalischen Handschriften in Deutschland 10,2).

WaLDSChMidT, Ernst 1971: Sanskrithandschriften aus den Turfanfunden. Teil 3. Die Katalognummern 802-1014. Unter Mitarbeit von Walter Clawiter und Lore Sander-Holzmann. Wiesbaden: Steiner (Verzeichnis der orientalischen Handschriften in Deutschland 10, 3).

WiLle, Klaus 1989: Sanskrithandschriften aus den Turfanfunden. Teil 6. Die Katalognummern 1202-1599. Wiesbaden: Steiner (Verzeichnis der orientalischen Handschriften in Deutschland 10,6).

WiLLE, Klaus 1995: Sanskrithandschriften aus den Turfanfunden. Teil 7. Die Katalognummern 1600-1799. Wiesbaden: Steiner (Verzeichnis der orientalischen Handschriften in Deutschland 10,7). 
WiLLE, Klaus 2000: Sanskrithandschriften aus den Turfanfunden. Teil 8. Die Katalognummern 1800-1999. Stuttgart: Steiner (Verzeichnis der orientalischen Handschriften in Deutschland 10,8).

WiLle, Klaus 2004: Sanskrithandschriften aus den Turfanfunden. Teil 9. Die Katalognummern 2000-3199. Herausgegeben von Heinz Bechert. Stuttgart: Steiner (Verzeichnis der orientalischen Handschriften in Deutschland 10, 9).

WiLLE, Klaus 2008: Sanskrithandschriften aus den Turfanfunden. Teil 10. Die Katalognummern 3200-4362. Stuttgart: Steiner (Verzeichnis der orientalischen Handschriften in Deutschland 10, 10).

WiLLE, Klaus 2012: Sanskrithandschriften aus den Turfanfunden. Teil 11. Die Katalognummern 4363-5799. Stuttgart: Steiner (Verzeichnis der orientalischen Handschriften in Deutschland 10,11). 